\title{
Die lewensiklus van Meloidogyne enterolobii en ander termofiliese Suid-Afrikaanse Meloidogyne spesies: 'n Vergelykende studie
}

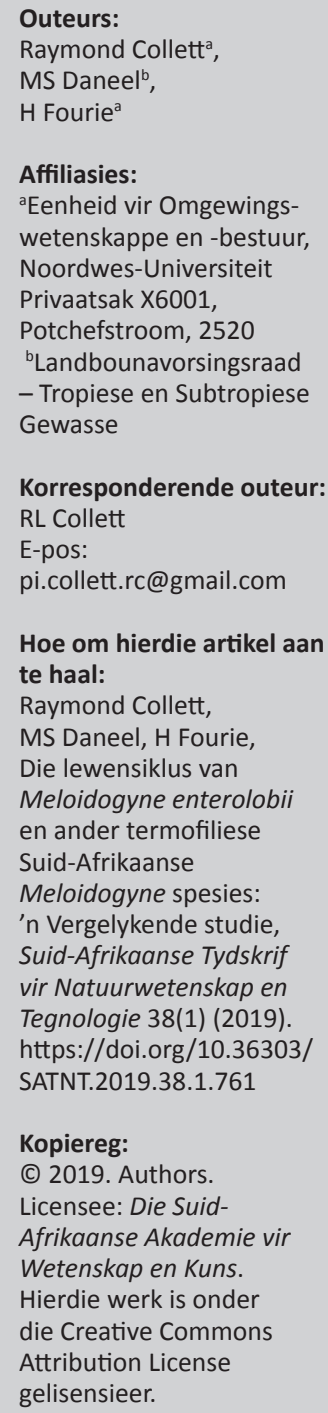

\begin{abstract}
The life cycle of Meloidogyne enterolobii and other thermophilic South African Meloidogyne species: a comparative study: Little is known about the life cycle of the rootknot nematode species Meloidogyne enterolobii that is present in South African fruit, grain, and vegetable productions, when compared to those of other economically thermophilic species. This information can contribute towards employing effective management strategies to combat this emerging threat.
\end{abstract}

Die knopwortelaalwurmspesie Meloidogyne enterolobii kom in plaaslike produksiegebiede, waar graan, groente en vrugte geproduseer word, voor. Dit is reeds in 1997 in die wortels van koejawelbome (Mbombela-omgewing) gevind, maar geen studies oor die lewensiklus en voortplantingspotensiaal van plaaslike bevolkings is egter gedoen nie.

Die lewensiklus van 'n plaaslike $M$. enterolobii bevolking is met dié van $M$. incognita en $M$. javanica in 'n glashuiseksperiment oor 'n 30-dag periode vergelyk. 'n Fotoperiode van 14L:10D en temperatuurreeks, wat gewissel het van 23 (minimum) tot $29{ }^{\circ} \mathrm{C}$ (maksimum), is in stand gehou. Altesaam 580 infektiewe, tweede jeugstadia (J2) van elk van die onderskeie knopwortelaalwurmspesies is op die wortels van tweeblaarstadium tamatiesaailinge geïnokuleer wat in Telone II-berookte grond geplant en ontkiem is. Drie dae na inokulasie (3DNI) en indringing van die $\mathrm{J} 2$ is die eerste wortelmonsters geneem, terwyl die res van die saailinge oorgeplant is in 500-ml buise in grond van dieselfde bron as wat vir saailingontkieming gebruik is. Die lewensiklusontwikkelingstadia van elke spesie is voorts ook bepaal deur op 5, 10, 15, 20, 25, en 30 DAI (ses monsternemings insluitend die 3DAI) wortelmonsters te neem. Vyf herhalings vir elke spesie is per monsterneming ingesluit.

Die J2-binne-inwortels is met suur fuchsin gekleur, waarna die wortelweefsel met laktogliserol ontkleur is. Vervolgens is 15 individue per spesie uit die wortels verwyder vir elke monsternemingsinterval om sodoende die aantal spesifieke lewenstadia te bepaal. Betekenisvolle interaksies $(\mathrm{P} \leq 0.05)$ is vir spesies $\mathrm{x}$ monsternemingsintervalle waargeneem vir infektiewe J2, vierde jeugstadia (J4) en wyfies, maar nie vir geswolle J2 en derde jeugstadia (J3) nie.

Meloidogyne enterolobii en M. javanica het die hoogste aantal J2 gehad, naamlik drie DNI, terwyl dieselfde tendens vir $M$. incognita 10 DNI gevind is. Op 20 DNI was ontwikkeling van J4 optimaal vir M. enterolobii, maar vir M. incognita en $M$. javanica eers 25 DNI. Volwasse wyfies vir M. enterolobii en $M$. javanica is vanaf $25 \mathrm{DNI}$ gevind in vergelyking met dié van $M$. incognita waarvoor $30 \mathrm{DNI}$ aangeteken is. Alhoewel geen eiers tydens die duur van die eksperiment in eierpakkies teenwoordig was nie, het $M$. enterolobii wyfies wel eierpakkies (wat net uit die gelatinmatriks bestaan het) geproduseer. Die duur van die eksperiment was dus te kort vir die wyfie om eiers te produseer en opvolgeksperimente sal dus na 35 dae verleng word om die resultate te verifieer.

Die plaaslike M. enterolobii het 294DD benodig om tot volwasse wyfies met eierpakkies (wat geen eiers bevat het nie) te ontwikkel. Dieselfde is vir M. incognita gevind, maar wyfies van die laasgenoemde spesie het egter nie eierpakkies geproduseer nie. Desnieteenstaande het M. javanica 213 DD benodig om tot volwasse wyfies te ontwikkel (ook met geen eierpakkieproduksie). Resultate het dus getoon dat die M. Enterolobii-bevolking vinniger tot eierpakkie-produserende wyfies ontwikkel het as die M. Incognita- en M. javanica-bevolkings, wat' $n$ aanduiding kan wees waarom die eersgenoemde spesie as meer skadelik beskou word.

Nota: 'n Seleksie van referaatopsommings: Studentesimposium in die Natuurwetenskappe, 25-26 Oktober 2018, SA Akademiegebou, Pretoria, Suid-Afrika. Gasredakteurs: Prof Rudi Pretorius (Departement Geografie, Universiteit van Suid-Afrika); Prof Chris Swanepoel (Departement Besluitkunde, Universiteit van Suid-Afrika); Me Andrea Lombard (Departement Geografie, Universiteit van Suid-Afrika) 